\title{
Mucocutaneous leishmaniasis treated with liposomal amphotericin B
}

\author{
Leishmaniose cutâneo mucosa tratada \\ com anfotericina B lipossomal
}

José Roberto Lambertucci ${ }^{1}$ and Luciana Cristina dos Santos Silva ${ }^{1}$

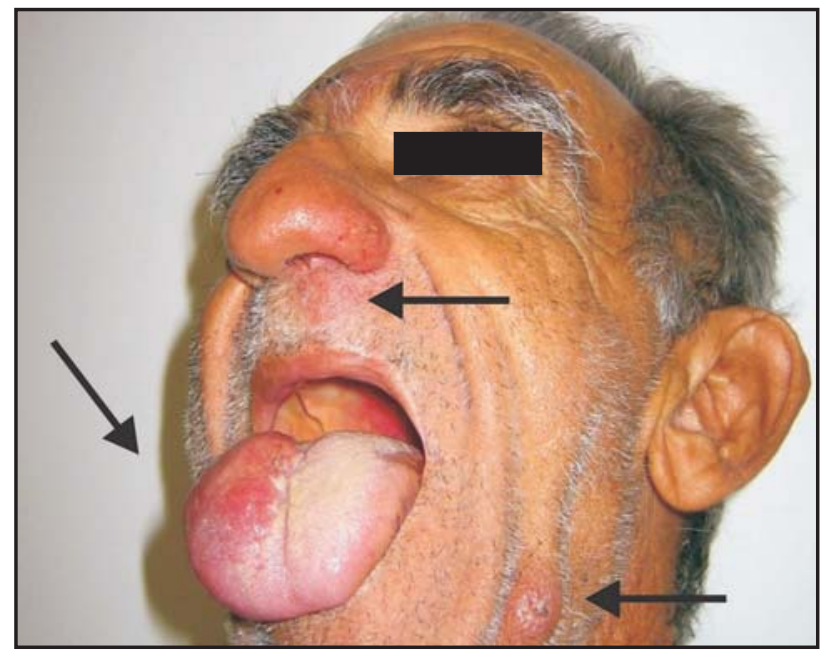

$\mathbf{A}$

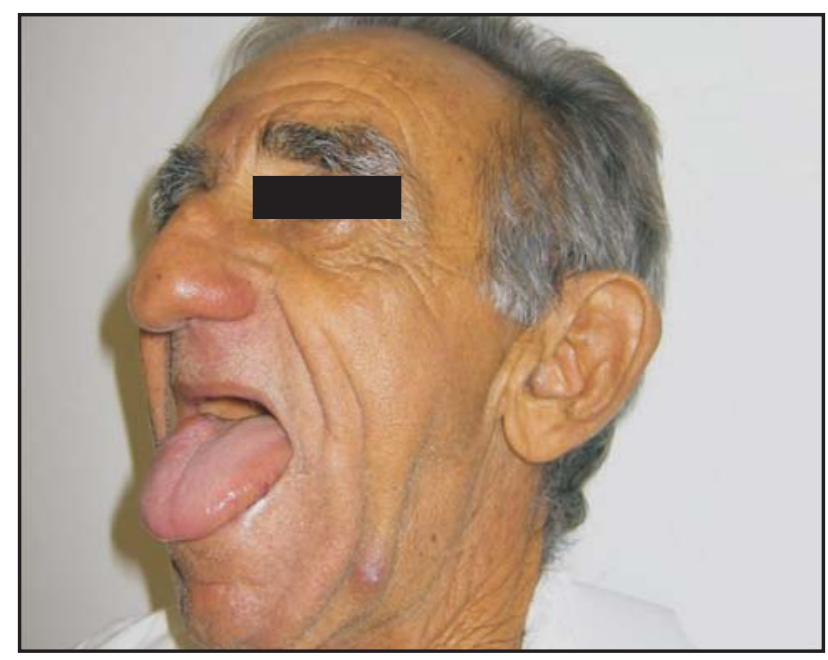

B

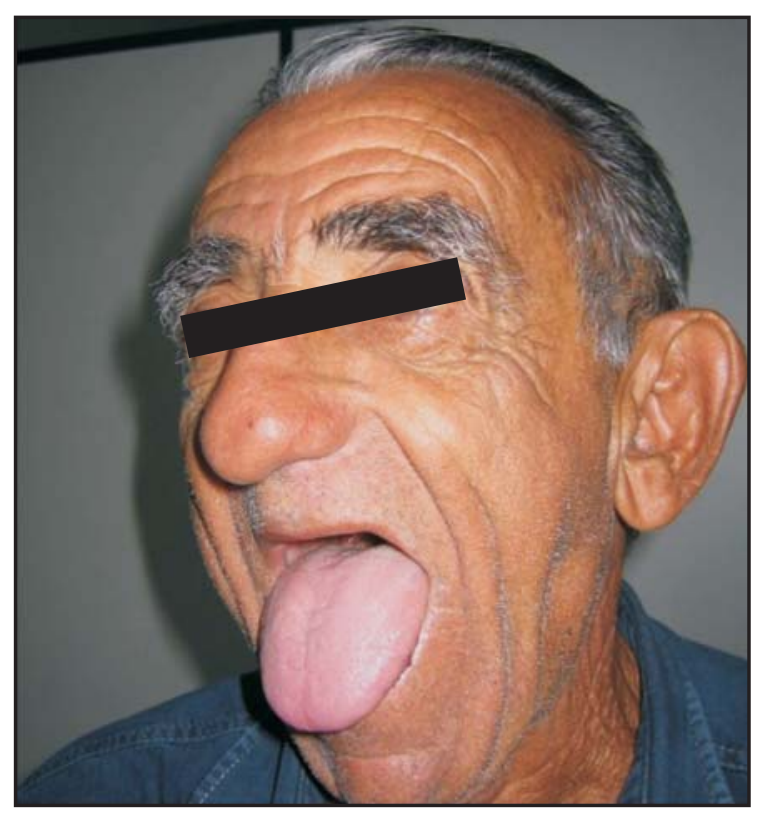

C

1.Curso de Pós-Graduação em Medicina Tropical, Departamento de Clínica Médica, Faculdade de Medicina, Universidade Federal de Minas Gerais, Belo Horizonte, MG. Address to: Prof. José Roberto Lambertucci. Dept ${ }^{\circ}$ de Clínica Médica/FM/UFMG. Av. Alfredo Balena 190, 30130-100 Belo Horizonte, MG.

e-mail: lamber@uai.com.br

Recebido para publicação em: 10/12/2007

Aceito em: 17/12/2007 
A 68-year-old man came to hospital complaining about the appearance and progression of one skin and two mucosal lesions. The skin lesion was an ulcerated nodule on his face (Figure A - arrow). There was erythematous infiltration of the skin around the nose (Figure A - arrow) and three ulcers in the left nostril. A tumorlike growth was also observed on the tongue (Figure A-arrow). He underwent a skin biopsy and three biopsies from the nasal mucosa. Examination under the microscope revealed the presence of amastigotes of Leishmania. The indirect immunofluorescence test for leishmaniasis was positive (1/100). He was treated with intravenous liposomal amphotericin B (3mg/kg of body weight for five days), followed by the same dosage on days 7, 14 and 21. Figure B shows the patient one month after starting treatment and Figure $\mathrm{C}$, six months later. He has been followed up as an outpatient for two years now with no relapse of the disease.

0 paciente, de 68 anos, procurou o hospital relatando 0 aparecimento e progressão de uma lesão de pele e duas lesões mucosas. A lesão na pele era um nódulo ulcerado na face (Figura A - seta). Havia infiltração eritematosa da pele em torno do nariz (Figura A - seta) e três úlceras na narina esquerda. Uma lesão tumoral também foi observada na língua (Figura A - seta). Ele submeteu-se a uma biópsia da pele e três da mucosa nasal e o exame microscópico relevou a presença de amastigotas de Leishmania. A imunofluorescência indireta para leishmaniose resultou positiva (1/100). 0 tratamento foi feito com anfotericina B lipossomal intravenosa (3mg/kg de peso, por cinco dias), seguido da mesma dosagem nos dias 7, 14 e 21. A Figura B mostra o paciente um mês após o tratamento, e a Figura C, o mesmo paciente seis meses mais tarde. Ele esteve em acompanhamento ambulatorial nos últimos dois anos e não apresentou recidiva da doença.

\section{REFERENCES}

1. Lambertucci JR, Coulaud R, Silva LC. Mucosal leishmaniasis. Revista da Sociedade Brasileira de Medicina Tropical 36: 307-308, 2003.

2. Prata A, Silva-Vergara ML, Costa L, Rocha A, Krolewiecki A, Silva JC, Paula EV, Pimenta Junior FG, Giraldo LE. Efficacy of azithromycin in the treatment of cutaneous leishmaniasis. Revista da Sociedade Brasileira de Medicina Tropical 36: 65-69, 2003.

3. Sampaio RN, Marsden PD. Treatment of the mucosal form of leishmaniasis without response to glucantime with liposomal amphotericin B. Revista da Sociedade Brasileira de Medicina Tropical 30: 125-128, 1997. 